\title{
TNF $\alpha$ enhances the motility and invasiveness of prostatic cancer cells by stimulating the expression of selective glycosyl- and sulfotransferase genes involved in the synthesis of selectin ligands.
}

\author{
Prakash Radhakrishnan \\ University of Nebraska Medical Center, pradhakr@unmc.edu \\ Vishwanath Chachadi \\ University of Nebraska Medical Center \\ Ming-Fong Lin \\ University of Nebraska Medical Center, mlin@unmc.edu \\ Rakesh Singh \\ University of Nebraska Medical Center, rsingh@unmc.edu \\ Reiji Kannagi
Aichichow Cancer Center \\ Follow this and additional works at: https://digitalcommons.unmc.edu/com_bio_articles \\ Part of the Medical Biochemistry Commons, and the Medical Molecular Biology Commons \\ See next page for additional authors
}

\section{Recommended Citation}

Radhakrishnan, Prakash; Chachadi, Vishwanath; Lin, Ming-Fong; Singh, Rakesh; Kannagi, Reiji; and Cheng, Pi-Wan, "TNF $\alpha$ enhances the motility and invasiveness of prostatic cancer cells by stimulating the expression of selective glycosyl- and sulfotransferase genes involved in the synthesis of selectin ligands." (2011). Journal Articles: Biochemistry \& Molecular Biology. 42.

https://digitalcommons.unmc.edu/com_bio_articles/42

This Article is brought to you for free and open access by the Biochemistry \& Molecular Biology at DigitalCommons@UNMC. It has been accepted for inclusion in Journal Articles: Biochemistry \& Molecular Biology by an authorized administrator of DigitalCommons@UNMC. For more information, please contact digitalcommons@unmc.edu. 


\section{Authors}

Prakash Radhakrishnan, Vishwanath Chachadi, Ming-Fong Lin, Rakesh Singh, Reiji Kannagi, and Pi-Wan Cheng 


\title{
TNFa enhances the motility and invasiveness of prostatic cancer cells by stimulating the expression of selective glycosyl- and sulfotransferase genes involved in the synthesis of selectin ligands
}

\author{
Prakash Radhakrishnan ${ }^{a}$, Vishwanath Chachadia, Ming-Fong Lin ${ }^{a, b}$, Rakesh Singh $^{\mathrm{b}, \mathrm{c}}$, Ajit \\ Varki $^{\mathrm{d}}$, Reiji Kannagi ${ }^{\mathrm{e}}$, and Pi-Wan Cheng ${ }^{\mathrm{a}, \mathrm{b},{ }^{*}}$ \\ aDepartment of Biochemistry and Molecular Biology, College of Medicine, University of Nebraska \\ Medical Center, Omaha, NE 68198 \\ ${ }^{b}$ Eppley Cancer Center for Research in Cancer and Allied diseases, University of Nebraska \\ Medical Center, Omaha, NE 68198 \\ 'Department of Pathology and Microbiology University of Nebraska Medical Center, Omaha, NE \\ 68198 \\ dUniversity of California at San Diego, San Diego, CA \\ ${ }^{\mathrm{e} A i c h i}$ Cancer Center, Nagoya, Japan
}

\begin{abstract}
Sialyl Lewis $\mathrm{X}\left(\mathrm{sLe}^{\mathrm{X}}\right)$ plays an important role in cancer metastasis. But, the mechanism for its production in metastatic cancers remains unclear. The objective of current study was to examine the effects of a pro-inflammatory cytokine on the expression of glycosyltransferase and sulfotransferase genes involved in the synthesis of selectin ligands in a prostate cancer cell line. Androgen-independent human lymph node-derived metastatic prostate cancer cells (C-81 $\mathrm{LNCaP}$ ), which express functional androgen receptor and mimic the castration-resistant advanced prostate cancer, was used. TNFa treatment of these cells increased their binding to P-, E- and Lselectins, anti-sLe ${ }^{\mathrm{x}}$ antibody, and anti-6-sulfo-sialyl Lewis $\mathrm{x}$ antibody by 12, 240, 43, 248 and $21 \%$, respectively. Also, the expression of C2GnT-1, B4GalT1, GlcNAc6ST3, and ST3Gal3 genes was significantly upregulated. Further treatment of TNFa-treated cells with either anti-sLe ${ }^{\mathrm{x}}$ antibody or E-selectin significantly suppressed their in vitro migration (81 and 52\%, respectively) and invasion ( 45 and $56 \%$, respectively). Our data indicate that TNFa treatment enhances the motility and invasion properties of LNCaP C-81 cells by increasing the formation of selectin
\end{abstract}

(C) 2011 Elsevier Inc. All rights reserved

*Corresponding author: Dr. Pi-Wan Cheng, Department of Biochemistry and Molecular Biology, College of Medicine, 985870 Nebraska Medical Center, University of Nebraska Medical Center, Omaha, NE 68198-5870, Tel: 402 559-5776, Fax: 402 559-6650, pcheng@unmc.edu.

Publisher's Disclaimer: This is a PDF file of an unedited manuscript that has been accepted for publication. As a service to our customers we are providing this early version of the manuscript. The manuscript will undergo copyediting, typesetting, and review of the resulting proof before it is published in its final citable form. Please note that during the production process errors may be discovered which could affect the content, and all legal disclaimers that apply to the journal pertain. 
ligands through stimulation of the expression of selective glycosyl- and sulfotransferase genes.

These results support the hypothesis that inflammation contributes to cancer metastasis.

\section{Keywords}

LNCaP cells; sLe ${ }^{\mathrm{x}}$; TNFa; glycogenes; motility and invasion

\section{Introduction}

Prostate cancer is the second leading cause of cancer death of men in the United States [1]. At the time of initial diagnosis, more than $70 \%$ of prostate cancer patients have lymph node metastases [2-5]. Although metastasis is the primary cause of the fatalities of cancer patients, the mechanism is not completely understood. One key step in the cancer metastatic process is the adhesion of circulating cancer cells to the endothelium at distant sites. This step involves selectin-ligand interactions between host cells (selectins) and cancer cells (selectin ligands). Understanding how the production of these two key players is regulated during cancer progression could help develop cancer therapeutic strategy.

Selectins are a family of type II transmembrane proteins found on the surface of leukocytes, platelets and activated endothelial cells. They are calcium-dependent C-type lectins [6]. The three major types of selectins include E-, P-, and L-selectins, which are located on endothelium, platelets and activated endothelium, and leukocytes, respectively [6]. The naturally occurring vascular carbohydrate ligands for these selectins include E-selectin ligand-1 (ESL-1), P-selectin glycoprotein ligand-1 (PSGL-1), CD34, cutaneous lymphocyteassociated antigen (CLA), glycoprotein GlyCAM-1, MAdCAM-1, Podocalyxin-like protein and Sgp200 [7]. These selectin-ligand interactions were originally shown to be involved in the trafficking of immune cells to inflamed tissues [8] and lymphoid organs, and recently in the metastasis of cancer cells [9]. The naturally occurring vascular ligands for these selectin molecules are mostly mucin-type glycoproteins which carry sialylated, fucosylated and sulfated glycans [10] although some $\mathrm{N}$-linked glycans also can participate in this process [11]. Increased expression and altered glycosylation of mucins are prominent features of carcinoma progression [10]. For example, sialyl Lewis $\mathrm{x}\left(\mathrm{sLe}^{\mathrm{x}}\right)$ and sialyl lewis a $\left(\mathrm{sLe}^{\mathrm{a}}\right)$ are increased substantially in tumors [12], including prostate cancers [13, 14]. Elevated expression of $\mathrm{sLe}^{\mathrm{x}}$ and $\mathrm{sLe}^{\mathrm{a}}$ on mucin type O-glycans is highly correlated with lymphatic and venous invasion of cancerous cells $[15,16] . \mathrm{SLe}^{\mathrm{x}}$ and 6 -sulfo-sLe ${ }^{\mathrm{x}}$ also were elevated under in vivo inflammatory condition [9] and in vitro induction with proinflammatroy cytokine, tumor necrosis factor a $(\mathrm{TNFa})[17,18]$. Glycosyland sulfotransferases responsible for the biosynthesis of the above mentioned epitopes were selectively upregulated in various cancers [19] and inflammatory conditions [9] and/or cells treated with TNFa $[17,18]$. However, a concerted effort to correlate the effects of inflammatory cytokine on the expression of selectin ligands, glycosyl- and sulfotransferase genes responsible for the synthesis of these ligands, interactions of these ligands with selectins, and the acquisition of metastatic potential of the TNFa-treated cells was lacking. 
Recently, serum TNFa level was found to be increased in prostate cancer patients with metastatic disease and elevated PSA [20]. This observation prompted us to examine whether $\mathrm{TNFa}$ could enhance the metastatic potential of prostate cancer cells via stimulating the production of $\mathrm{sLe}^{\mathrm{x}}$, an important determinant of cancer metastasis. To carry out a more comprehensive study on the effect of TNFa on the acquisition of the sLe ${ }^{\mathrm{x}}$-related metastatic potential in prostate cancer, we employed LNCaP C-81 cells, which exhibit properties mimicking the clinical characteristics of advanced prostate cancers [21-23]. C-81 cells are androgen independent, grow faster and have high colony-forming property on soft agar as compared to LNCaP parental C-33 cells [22]. We found that treatment of the C-81 LNCaP cells with TNFa increased the motility and invasiveness, which accompanied an increase in selectin ligands resulted from elevated expression of selected glycosyl- and sulfotransferase genes.

\section{Materials and methods}

\subsection{Cell lines}

The human Prostate cancer cell line LNCaP was originally purchased from the American Type Culture Collection ATCC (Rockville, MD). The LNCaP cell model including C-33 and C-81 cells used in the present study was developed by Lin et al [22] and further characterized by Igawa et al [21]. The cell line was maintained in RPMI 1640 medium supplemented with 5\% Fetal bovine serum, 1\% L-glutamine and 1\% PenicillinStreptomycin.

\subsection{Flow Cytometry analysis of selectin interactions with ligands on LNCaP cells}

Flow cytometry analysis of selectin-ligand interaction on cancer cells was carried out as described previously [24]. Briefly, LNCaP cells of both control and TNFa (20 ng/ml, $36 \mathrm{~h}$ ) treated were detached from plates after incubation with PBS containing 2 mM EDTA for 5 min at $37^{\circ} \mathrm{C}$, washed three times with Hanks' balanced salt solution (HBSS), and then treated with $0.5 \%$ BSA in HBSS for 30 min to block nonspecific binding. Chimeras of selectins $\mathrm{P}(50 \mu \mathrm{g} / \mathrm{ml}), \mathrm{E}(50 \mu \mathrm{g} / \mathrm{ml})$, and $\mathrm{L}(50 \mu \mathrm{g} / \mathrm{ml})$ fused with Fc region of human $\operatorname{IgG}$ were purified from human 293 cells (transformed embryonic kidney fibroblast cell line) of Psel IgG, ESIg B3293 and LSRg293 Cytel, respectively [24]. These selectins were preincubated with a goat-anti human IgG conjugated with FITC for $1 \mathrm{~h}$ at room temperature. Similarly, sLe ${ }^{\mathrm{x}}$ (KM93) $(10 \mu \mathrm{g} / \mathrm{ml})$ and 6-sulfo-sLe ${ }^{\mathrm{x}}$ (G152) (1:10 diluted) [25] mouse monoclonal antibodies were pre-incubated with goat anti-mouse antibody conjugated with FITC before use. These complexes (Selectin, KM93 Ab, or G152 Ab complexed with respective FITC-conjugated secondary antibodies) were incubated with tumor cells at $4{ }^{\circ} \mathrm{C}$ for $2 \mathrm{~h}$ and then washed successively with HBSS/BSA and HBSS. Then cells were fixed with $2 \%(\mathrm{wt} / \mathrm{vol})$ paraformaldehyde in HBSS at room temperature for 15-30 min. The cells were then washed with HBSS and resuspended in $1 \mathrm{ml}$ of HBSS/BSA for flow cytometry analysis. Controls were cells stained in a presence of $5 \mathrm{mM}$ EDTA (calcium chelation) or 30 mM EDTA in the case of P-selectin. In some instances, tumor cell surfaces were pretreated before probing for selectin ligands. Cells treated with FITC-conjugated secondary antibody alone served as an antibody control. 


\subsection{Real Time PCR analysis of the expression of glycosyl- and sulfotransferase genes}

RT-PCR analyses on LNCaP C-81 cells were performed as described previously [26]. Total cellular RNAs were isolated from TNFa treated $(20 \mathrm{ng} / \mathrm{ml}, 3 \mathrm{~h})$ and control LNCaP cells using the TRI-REAGENT (Molecular Research Center, Inc, USA) according to the manufacturer protocol. cDNA was synthesized by using $2 \mu \mathrm{g}$ of total RNA as the template in a $20 \mu \mathrm{RT}$ reaction mixture by using Verso ${ }^{\mathrm{TM}}$ cDNA kit (ABgene, UK) according to the manufacturer instruction. Quantitative real time PCR was performed on a Master cycler ep realplex $^{2}$ (Eppendorf AG, Hamburg) using SYBR Green PCR kit (Takara Bio Inc, USA). The forward and reverse primers used for amplification of selective glycosyl- and sulfotransferase genes are listed in Table 1. The data were analyzed using Eppendorf realplex software, version 1.5 (Eppendorf). The amounts of various glycogene transcripts were normalized to the amount of GAPDH transcript in same cDNA sample and expressed as $\%$ of GAPDH. Relative fold differences in transcript expression were determined using the following comparative CT method: $2^{-[\mathrm{aCt}(\mathrm{TNFa})-\mathrm{aCt}(\mathrm{Control})]}=2^{-\mathrm{a} \mathrm{Ct}}$, where $\mathrm{aC}_{\mathrm{t}}=\mathrm{C}_{\mathrm{t}}($ Target $)-\mathrm{C}_{\mathrm{t}}($ GAPDH $)$ as described previously [26]. The results were expressed as the amount $(\%)$ relative to that $(100 \%)$ of GAPDH and plotted as mean fold changes \pm SEM.

\subsection{Motility and Invasion assays}

Motility and invasion assays were performed as previously described [23]. For motility assays, $5 \times 10^{4}$ cells $/ \mathrm{ml}$ of control, TNFa treated $(20 \mathrm{ng} / \mathrm{ml}, 36 \mathrm{~h})$, and TNFa treated cells further incubated with sLe ${ }^{\mathrm{x}}$ monoclonal antibody KM93 $(10 \mu \mathrm{g} / \mathrm{ml})$ or E-selectin $(100$ $\mu \mathrm{g} / \mathrm{ml}$ ) were placed on the top chamber of non-coated polyethylene terapthalate membranes. After incubation for $24 \mathrm{~h}$, the cells that did not migrate through the pores in the membrane were removed by scraping the membrane with a cotton swab. Cells that transversed the membranes were stained with a Diff-Quick cell staining kit (Dade Behring, Inc., Newark, DE). Invasion assay of prostate cancer cells was carried out as described above except that 24 well BD BioCoat ${ }^{\mathrm{TM}}$ Matrigel ${ }^{\mathrm{TM}}$ invasion chambers ( $8 \mu \mathrm{m}$ pore size; Becton Dickinson) were used and the incubation time was $22 \mathrm{~h}$. Cells at three random fields per insert were counted with $40 \times$ magnification and expressed as the average number of cells per field of view. Three independent experiments were performed in triplicates in each condition. The data were presented as the mean of three independent experiments \pm SD.

\subsection{Statistical Analysis}

The Student's t-test was used for analysis of the significance of differences in means between control and tested samples. $\mathrm{P}<0.05$ was considered significant.

\section{Results}

\subsection{TNFa enhancement of selectin binding to LNCaP cells}

LNCaP C-81 cells with and without TNFa treatment were assessed for their binding to P-, E-, and L-selectins by flow cytometry. These cells exhibited a decreasing order of selectin binding, P-selectin $>$ L-selectin $>$ E-selectin, in the untreated controls (Figs. 1A-C). TNFa treatment increased the number of cells that bind to E, P, and L-selectins by $240 \%$ $(\mathrm{p}<0.001), 12 \%(\mathrm{p}<0.05)$, and $43 \%(\mathrm{p}<0.05)$, respectively (Fig. 1A-C). 


\subsection{TNFa enhancement of sLe ${ }^{x}$ and 6-sulfo-sLe ${ }^{x}$ epitopes on LNCaP cells}

The E- and L-selectin ligands, $\mathrm{SLe}^{\mathrm{x}}$ and 6-sulfo-sLe ${ }^{\mathrm{x}}$, on C-81 LNCaP cells were assessed with KM93 and G152 antibodies, respectively. As shown in Fig. 2A and 2B, TNFa treatment increased the binding of LNCaP cells to KM93 and G152 antibodies by $248 \%$ $(\mathrm{p}<0.001)$ and $21 \%(\mathrm{p}<0.05)$, respectively.

\subsection{TNFa modulation of the expression of glycosyl- and sulfotransferase genes involved in the synthesis of selectin ligands}

The TNFa-induced changes in the expression of the glycosyl- and sulfotransferase genes involved in the synthesis of mucin-type selectin ligands were assessed by real time PCR analysis. As shown in Fig. 3, TNFa treatment of LNCaP cells significantly increased the expression of the following genes (\% increase over the control): $C 2 G n T 1(340 \%)(\mathrm{p}<0.01)$, B4GalT1 (68\%) ( $\mathrm{p}<0.05)$, GlcNAc6ST3 (760\%) ( $<<0.01)$ and ST3Gal3 (240\%) ( $<<0.05)$. Although C1GALT1 gene expression was not affected by TNFa, it did express at a high basal level, i.e. $0.11 \%$ of GAPDH. However, the gene expression level of core 1 extension enzyme, $B 3 G n T 3$, was very low, i.e. $0.00006 \%$ of $G A P D H$. C2GnT1 is the highest expresser among the three $\mathrm{C} 2 \mathrm{GnT}$ isozymes. All B4GalTs were expressed at very high levels. After TNFa treatment, GlcNAc6ST1 \& 3 were expressed at modest levels, ST3Gal4 was the highest expresser among the three ST3Gal isozymes and FUT4 was the highest expresser among the FUT genes.

\subsection{TNFa enhancement of in vitro motility and invasion of LNCaP cells}

The motility and invasion properties of $\mathrm{LNCaP}$ cells treated with TNFa were analyzed by in vitro Boyden chamber assay. As shown in Fig. $4 \mathrm{~A}-4 \mathrm{C}$, TNFa treatment significantly increased the number of cells that migrated through polyethylene terapthalate membrane by $83 \%(\mathrm{p}<0.001)$ and those that invaded the matrigel by $44 \%(\mathrm{p}<0.001)$ when compared with the untreated cells. Incubation of the TNFa-treated cells with KM93 antibodies and Eselectin reduced the number of cells that migrated through polyethylene terapthalate membrane by $81 \%(\mathrm{p}<0.001)$ and $52 \%(\mathrm{p}<0.001)$, respectively, and those that invaded the matrigel by $45 \%(\mathrm{p}<0.001)$ and $56 \%(\mathrm{p}<0.001)$, respectively when compared with the cells treated with TNFa only.

\section{Discussion}

Metastasis is the primary cause of cancer death. and inflammation is a key contributor of cancer metastasis $[27,28]$. Current study shows that TNFa, a proinflammatory cytokine, enhances the motility and invasiveness of human prostate cancer cells by stimulating the expression of selective glycosyl- and sulfotransferase genes involved in the synthesis of selectin ligands. These results support the role of inflammation in cancer metastasis [29].

Cancer metastasis involves several highly coordinated steps, including escaping of tumor cells from the primary sites, transport of these cells by circulation to the lymphoid organs and/or distant sites, adhesion of these cells to the inflamed endothelium at these sites, and then establishment of tumors. Interactions of selectins and their ligands play a crucial role in the second and third steps of the metastatic process as described above. The circulating 
metastatic cancer cells provide $\mathrm{SLe}^{\mathrm{x}}$, an E-selectin ligand, to facilitate their arrest by the Eselectin present on the activated endothelium at distant sites [30,31]. The L-selectin ligand, 6-sulfo-sLe ${ }^{\mathrm{x}}$, expressed on the surface of these cancer cells help them adhere to the circulating leukocytes by binding to L-selectin expressed on the surface of leukocytes, which facilitates their transport to the lymphoid organs and inflamed endothelium at distant sites. The P-selectin ligand expressed on these cancer cells render these cells capable of adhering to P-selectin present on the activated endothelium at distant sites and on circulating platelets, which help these cancer cells to metastasize [30]. The increased expression of P-, E-, and L-selectin ligands on these cancer cells following treatment with TNFa could enhance the potential of these cells to target to the lymphoid organs and inflamed endothelium at distant sites. In this study, we have shown that TNFa enhances the motility and invasiveness of these prostate cancer cells. Confirmation of this observation in vivo remains to be made.

$\mathrm{SLe}^{\mathrm{x}}$ and 6-sulfo-sLe ${ }^{\mathrm{x}}$ can be found on core 1 and core 2 mucin glycans [31,32]. The formation of these glycotopes is controlled by the levels of these enzymes of which expression is subject to regulation [31,33]. For example, TNFa has been shown to increase the production of sialylated and/or sulfated Lewis $\mathrm{x}$ epitopes in the human bronchial mucosa by stimulating the expression of glycosyl- and sulfotransferases responsible for their synthesis [18]. The enzymes responsible for the enhancement of these glycotopes have been shown to be FUT3 \& 4, ST3Gal3 \& 4, and GlcNAc6STs. TNFa also can enhance the production of sulfated $\mathrm{N}$-acetyllactosamine, a precursor of 6-sulfo-sLe ${ }^{\mathrm{x}}$ on CD44 of a SR91 myloid cell line [34]. In this report, we showed increased production of P-, E-, and Lselectin ligands on LNCaP cells treated with TNFa. Upregulation of C2GnT-1, B4GalT1, GlcNAc6ST3 and ST3Gal3 genes coupled with high expression levels of additional glycosyland sulfotransferase genes can explain the formation of these selectin ligands in response to TNFa treatment. However, the low expression level (0.00005\% of GAPDH) of the core 1 extension enzyme (B3GnT3) suggests that the core 1 can not be extended to support the formation of these glycotopes on this core structure. Therefore, these selectin ligands are most likely localized to the core 2 branch. This prediction remains to be confirmed by glycan analysis.

We extended the biochemical and molecular biological observations by showing that TNFainduced changes in glycogene expression profile led to increased binding of these cells to P-, E-, and L-selectins, and increased their adhesion, motility, and invasion properties. This observation confirmed a previous report that TNFa increased migration and invasion of a human melanoma cell line [35]. Collectively, these results support the idea that inflammatory cytokines can enhance the metastatic properties of cancer cells and further substantiate the link between inflammation and cancer progression as previously described $[27,28]$.

In conclusion, the present study shows the TNFa effect on enhancement of prostate cancer cell migration and invasion through activation of selective glycosyl and sulfotransferase genes involved in the biosynthesis of sialylated and/or sulfated sLe ${ }^{\mathrm{x}}$. These genes may serve potential therapeutic targets. 


\section{Acknowledgments}

We wish to acknowledge the research support from NIH RO1 CA88184 (MFL), RO1 HL48282 and R21 HL97238, the State of Nebraska-NRI cancer glycobiology program and LB506 (PWC), and the Department of Defense Postdoctoral Fellowship (PR), and expert technical assistance of Helen Cheng.

\section{References}

1. Jemal A, Siegel R, Xu J, Ward E. Cancer statistics, 2010. CA Cancer. J. Clin. 2010; 60:277-300. [PubMed: 20610543]

2. Nelson WG, De Marzo AM, Isaacs WB. Prostate cancer. N. Engl. J. Med. 2003; 349:366-381. [PubMed: 12878745]

3. Borsig L, Wong R, Feramisco J, Nadeau DR, Varki NM, Varki A. Heparin and cancer revisited: Mechanistic connections involving platelets, P-selectin, carcinoma mucins, and tumor metastasis. Proc. Natl. Acad. Sci. U. S. A. 2001; 98:3352-3357. [PubMed: 11248082]

4. Imai Y, Singer MS, Fennie C, Lasky LA, Rosen SD. Identification of a carbohydrate-based endothelial ligand for a lymphocyte homing receptor. J. Cell Biol. 1991; 113:1213-1221. [PubMed: 2040648]

5. Hemmerich S, Butcher EC, Rosen SD. Sulfation-dependent recognition of high endothelial venules (HEV)-ligands by L-selectin and MECA 79, and adhesion-blocking monoclonal antibody. J. Exp. Med. 1994; 180:2219-2226. [PubMed: 7525849]

6. Varki A. Selectin ligands. Proc. Natl. Acad. Sci. U. S. A. 1994; 91:7390-7397. [PubMed: 7519775]

7. Yeh JC, Hiraoka N, Petryniak B, Nakayama J, Ellies LG, Rabuka D, Hindsgaul O, Marth JD, Lowe JB, Fukuda M. Novel sulfated lymphocyte homing receptors and their control by a Core1 extension beta 1,3-N-acetylglucosaminyltransferase. Cell. 2001; 105:957-969. [PubMed: 11439191]

8. Streeter PR, Rouse BT, Butcher EC. Immunohistologic and functional characterization of a vascular addressin involved in lymphocyte homing into peripheral lymph nodes. J. Cell Biol. 1988; 107:1853-1862. [PubMed: 2460470]

9. McEver RP. Selectin-carbohydrate interactions during inflammation and metastasis. Glycoconj. J. 1997; 14:585-591. [PubMed: 9298691]

10. Kim YJ, Borsig L, Han HL, Varki NM, Varki A. Distinct selectin ligands on colon carcinoma mucins can mediate pathological interactions among platelets, leukocytes, and endothelium. Am. J. Pathol. 1999; 155:461-472. [PubMed: 10433939]

11. Mitoma J, Bao X, Petryanik B, Schaerli P, Gauguet JM, Yu SY, Kawashima H, Saito H, Ohtsubo K, Marth JD, Khoo KH, von Andrian UH, Lowe JB, Fukuda M. Critical functions of N-glycans in L-selectin-mediated lymphocyte homing and recruitment. Nat. Immunol. 2007; 8:409-418. [PubMed: 17334369]

12. Ohyama C, Tsuboi S, Fukuda M. Dual roles of sialyl lewis X oligosaccharides in tumor metastasis and rejection by natural killer cells. EMBO J. 1999; 18:1516-1525. [PubMed: 10075923]

13. Martensson S, Bigler SA, Brown M, Lange PH, Brawer MK, Hakomori S. Sialyl-lewis(x) and related carbohydrate antigens in the prostate. Hum. Pathol. 1995; 26:735-739. [PubMed: 7628844]

14. Wei J, Cui L, Liu F, Fan Y, Lang R, Gu F, Guo X, Tang P, Fu L. E-selectin and sialyl lewis X expression is associated with lymph node metastasis of invasive micropapillary carcinoma of the breast. Int. J. Surg. Pathol. 2010; 18:193-200. [PubMed: 18611928]

15. Sumikura S, Ishigami S, Natsugoe S, Miyazono F, Tokuda K, Nakajo A, Okumura H, Matsumoto M, Hokita S, Aikou T. Disseminated cancer cells in the blood and expression of sialylated antigen in gastric cancer. Cancer Lett. 2003; 200:77-83. [PubMed: 14550955]

16. Jeschke U, Mylonas I, Shabani N, Kunert-Keil C, Schindlbeck C, Gerber B, Friese K. Expression of sialyl lewis X, sialyl lewis A, E-cadherin and cathepsin-D in human breast cancer: Immunohistochemical analysis in mammary carcinoma in situ, invasive carcinomas and their lymph node metastasis. Anticancer Res. 2005; 25:1615-1622. [PubMed: 16033070]

17. Ishibashi Y, Inouye Y, Okano T, Taniguchi A. Regulation of sialyl-lewis x epitope expression by TNF-alpha and EGF in an airway carcinoma cell line. Glycoconj. J. 2005; 22:53-62. [PubMed: 15864435] 
18. Delmotte P, Degroote S, Lafitte JJ, Lamblin G, Perini JM, Roussel P. Tumor necrosis factor alpha increases the expression of glycosyltransferases and sulfotransferases responsible for the biosynthesis of sialylated and/or sulfated lewis x epitopes in the human bronchial mucosa. J. Biol. Chem. 2002; 277:424-431. [PubMed: 11679593]

19. Kudo T, Ikehara Y, Togayachi A, Morozumi K, Watanabe M, Nakamura M, Nishihara S, Narimatsu H. Up-regulation of a set of glycosyltransferase genes in human colorectal cancer. Lab. Invest. 1998; 78:797-811. [PubMed: 9690558]

20. Michalaki V, Syrigos K, Charles P, Waxman J. Serum levels of IL-6 and TNF-alpha correlate with clinicopathological features and patient survival in patients with prostate cancer. Br. J. Cancer. 2004; 90:2312-2316. [PubMed: 15150588]

21. Igawa T, Lin FF, Lee MS, Karan D, Batra SK, Lin MF. Establishment and characterization of androgen-independent human prostate cancer LNCaP cell model. Prostate. 2002; 50:222-235. [PubMed: 11870800]

22. Lin MF, Lee MS, Zhou XW, Andressen JC, Meng TC, Johansson SL, West WW, Taylor RJ, Anderson JR, Lin FF. Decreased expression of cellular prostatic acid phosphatase increases tumorigenicity of human prostate cancer cells. J. Urol. 2001; 166:1943-1950. [PubMed: 11586265]

23. Radhakrishnan P, Lin MF, Cheng PW. Elevated expression of L-selectin ligand in lymph nodederived human prostate cancer cells correlates with increased tumorigenicity. Glycoconj. J. 2009; 26:75-81. [PubMed: 18670876]

24. Borsig L, Wong R, Hynes RO, Varki NM, Varki A. Synergistic effects of L- and P-selectin in facilitating tumor metastasis can involve non-mucin ligands and implicate leukocytes as enhancers of metastasis. Proc. Natl. Acad. Sci. U. S. A. 2002; 99:2193-2198. [PubMed: 11854515]

25. Mitsuoka C, Sawada-Kasugai M, Ando-Furui K, Izawa M, Nakanishi H, Nakamura S, Ishida H, Kiso M, Kannagi R. Identification of a major carbohydrate capping group of the L-selectin ligand on high endothelial venules in human lymph nodes as 6-sulfo sialyl lewis X. J. Biol. Chem. 1998; 273:11225-11233. [PubMed: 9556613]

26. Tassone F, Hagerman RJ, Taylor AK, Gane LW, Godfrey TE, Hagerman PJ. Elevated levels of FMR1 mRNA in carrier males: A new mechanism of involvement in the fragile-X syndrome. Am. J. Hum. Genet. 2000; 66:6-15. [PubMed: 10631132]

27. Balkwill F, Joffroy C. TNF: A tumor-suppressing factor or a tumor-promoting factor? Future Oncol. 2010; 6:1833-1836. [PubMed: 21142857]

28. Balkwill F. Tumor necrosis factor or tumor promoting factor? Cytokine Growth Factor Rev. 2002; 13:135-141. [PubMed: 11900989]

29. Clevers H. At the crossroads of inflammation and cancer. Cell. 2004; 118:671-674. [PubMed: 15369667]

30. Varki A. Selectin ligands. Proc. Natl. Acad. Sci. U. S. A. 1994; 91:7390-7397. [PubMed: 7519775]

31. Cheng, P-W.; Radhakrishnan, P. Mucin glycan branching enzymes: structure, function and gene regulation. In: Albert, Wu, editor. Molecular Immunology of Complex Carbohydrates-3. Vol. 705. N.Y.: Plenum Press, N.Y.; 2011. p. 465-492.Advances in Experimental Medicine and Biology

32. Kawashima H, Petryniak B, Hiraoka N, Mitoma J, Huckabyet V, Nakayama J, Uchimura K, Kadomatsu K, Lowe JB, Fukuda M. N-acetylglucosamine-6-O-sulfotransferases 1 and 2 cooperatively control lymphocyte homing through L-selectin ligand biosynthesis in high endothelial venues. Nature Immunology. 2005; 6:1096-1104. [PubMed: 16227985]

33. Brockhausen I. Mucin-type O-glycans in human colon and breast cancer: glycodynamics and functions. EMBO Rep. 2006; 7:599-604. [PubMed: 16741504]

34. Delcommenne M, Kannagi R, Johnson P. TNF-alpha increases the carbohydrate sulfation of CD44: Induction of 6-sulfo N-acetyl lactosamine on N- and O-linked glycans. Glycobiology. 2002; 12:613-622. [PubMed: 12244074]

35. Katerinaki E, Evans GS, Lorigan PC, MacNeil S. TNF-alpha increases human melanoma cell invasion and migration in vitro: The role of proteolytic enzymes. Br. J. Cancer. 2003; 89:11231129. [PubMed: 12966436] 


\section{Highlights}

In this communication, we have made the following observations.

$>\mathrm{TNFa}$, a proinflammatory cytokine, enhances the motility and invasiveness of prostate cancer cells.

$>\mathrm{TNFa}$ enhances the production of selectin ligands in prostate cancer cells, which results in increased binding to $\mathrm{P}-$, E-, and L-selectins.

$>\mathrm{TNFa}$ upregulates the expression of selective glycosyl- and sulfotransferase genes involved in the synthesis of selectin ligands. 
A

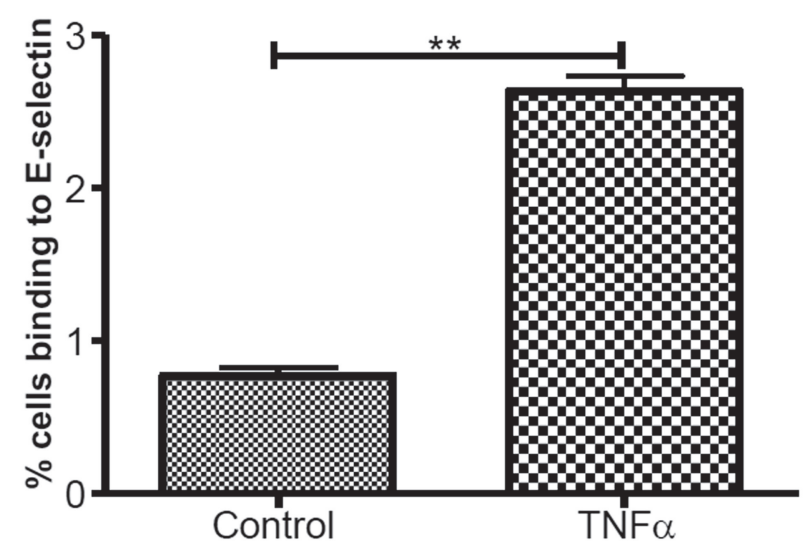

B
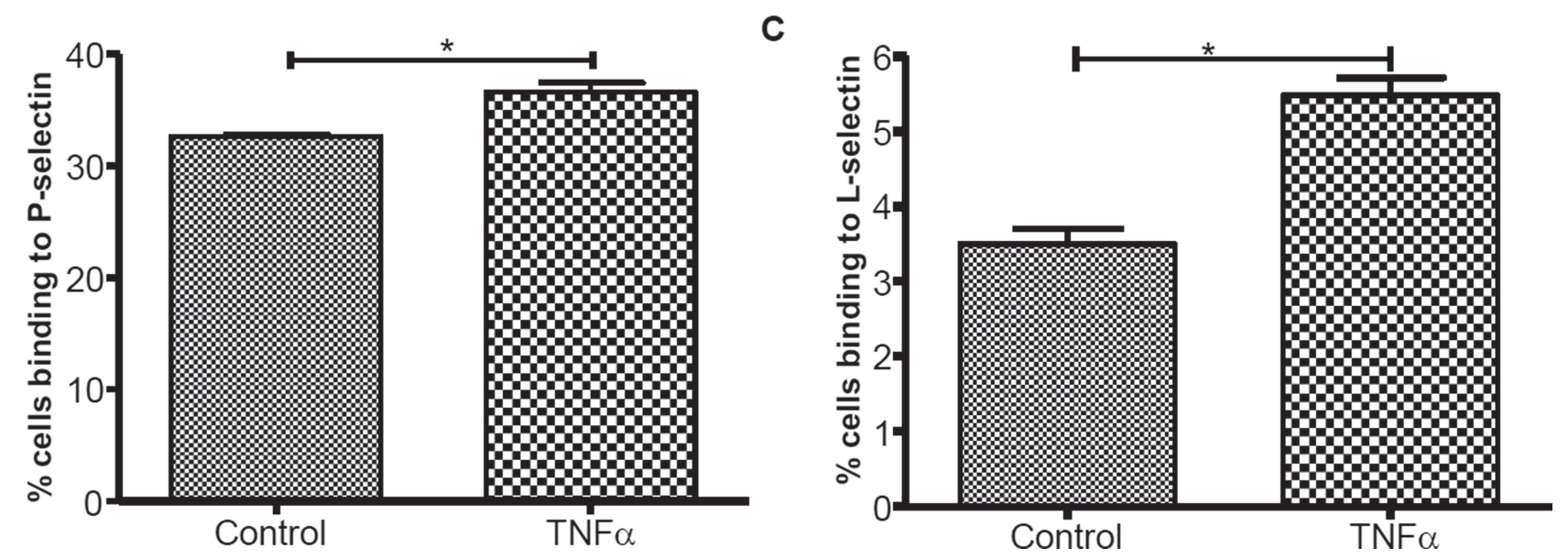

Fig. 1.

Interactions of selectins and ligands on LNCaP C-81 cells. The decreasing binding order of selectins with C-81 cells were $\mathrm{P}>\mathrm{L}$ $>$ E. Treatment of C-81 cells with TNFa $(20 \mathrm{ng} / \mathrm{ml}, 36 \mathrm{~h})$ significantly increased the binding of E-selectin (A), P-selectin (B) and L-selectin $(\mathrm{C})$ when compared with control cells $\left({ }^{*}, \mathrm{p}<0.05 ;{ }^{* *}, \mathrm{p}<0.001\right)$. 
A

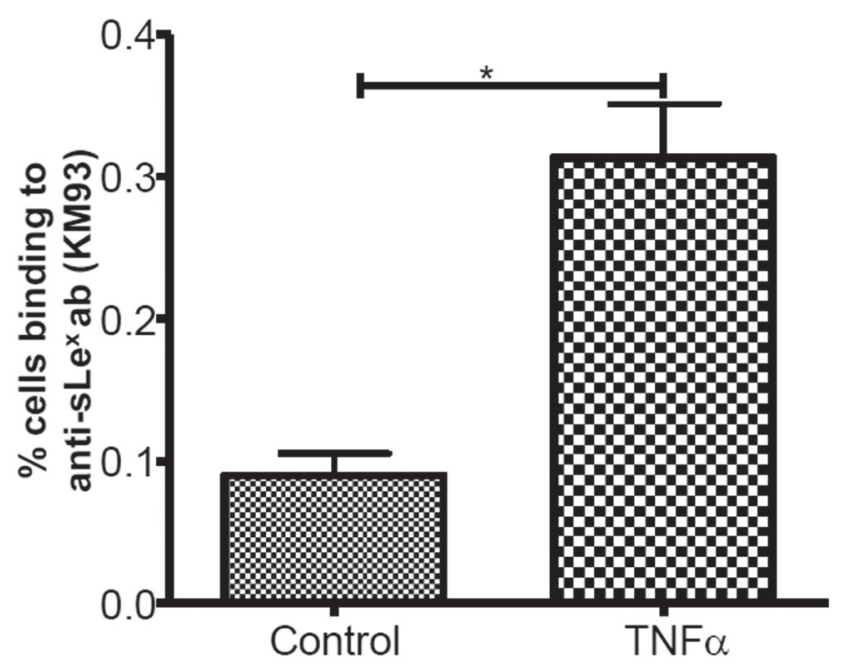

B

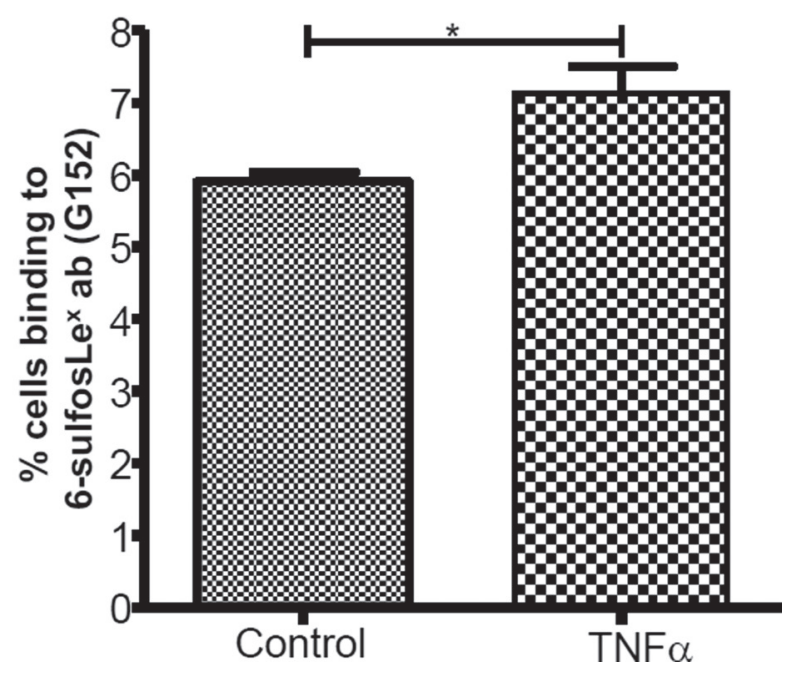

Fig. 2.

TNFa enhancement of sLe ${ }^{\mathrm{x}}$ and 6-sulfo-sLe ${ }^{\mathrm{x}}$ expression on LNCaP C-81 cells. Treatment of LNCaP cells with TNFa

$(20 \mathrm{ng} / \mathrm{ml}, 36 \mathrm{~h})$ significantly increased higher binding of these cells to anti-sLe ${ }^{\mathrm{x}}(\mathrm{A})$ and 6-sulfo-sLe ${ }^{\mathrm{x}}(\mathrm{B})$ antibodies $(*, \mathrm{p}<0.05$; $* *, \mathrm{p}<0.001)$. 


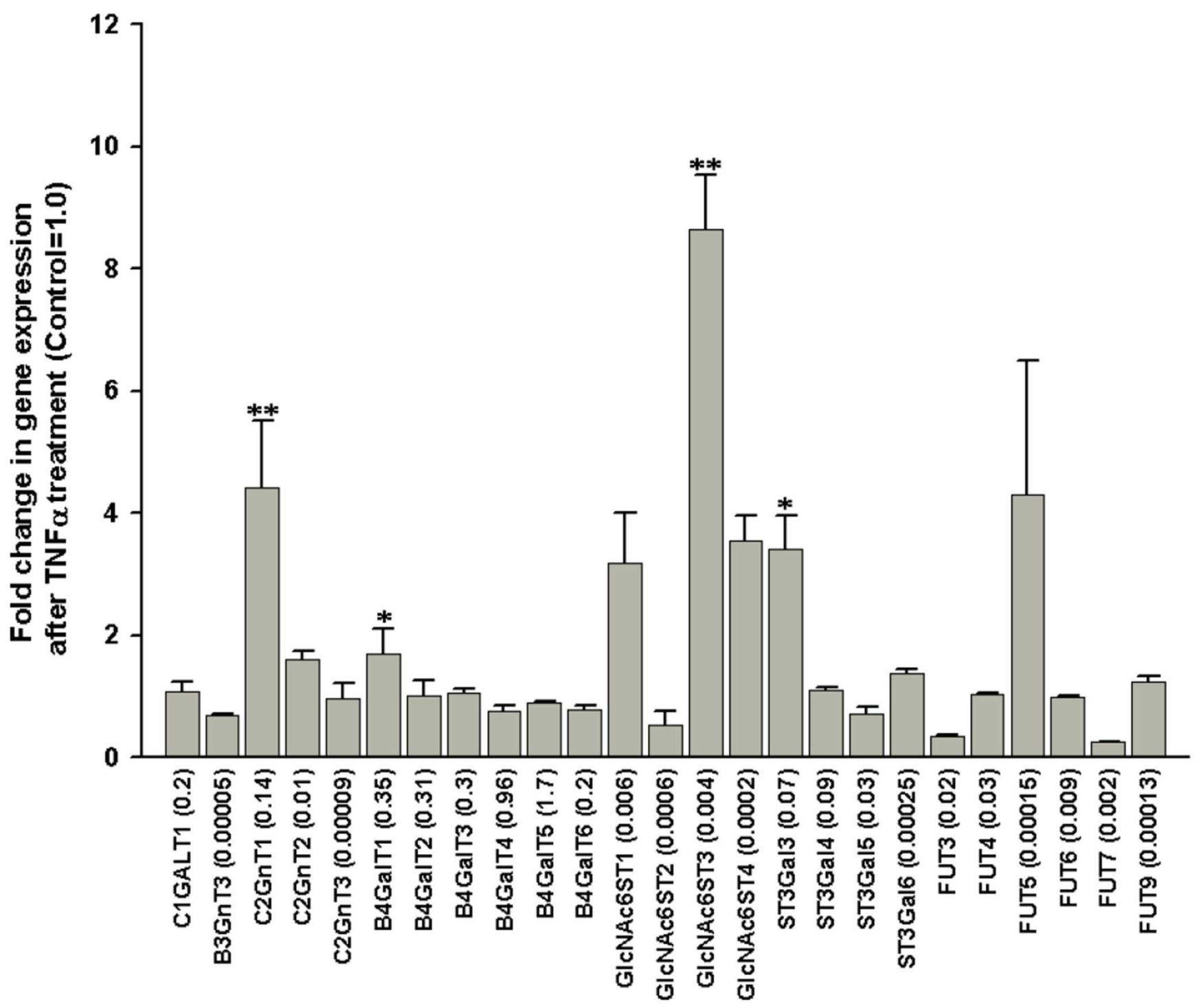

Fig. 3.

Quantitative RT-PCR analysis of glycosyl- and sulfotransferase gene expression. Quantitative real time PCR analysis was carried out on LNCaP cells with and without TNFa treatment (20 ng/ml, 3h). Relative expression level of each gene was sorted according to $\mathrm{Ct}$ (see Materials and Methods) calibrated with GAPDH and expressed as \% of GAPDH at basal levels and fold changes determined by calculating the ratio of the expression level of each gene in TNFa treated vs. vehicle-treated cells. Relative amount of each gene versus that of GAPDH (100\%) in untreated control cells was given in the parenthesis ( $\mathrm{n}=3$ ). Statistical analysis of the difference in means between treated and control cells for each gene was performed by the Student's ttest $(*, \mathrm{p}<0.05 ; * *, \mathrm{p}<0.01)$. 
A

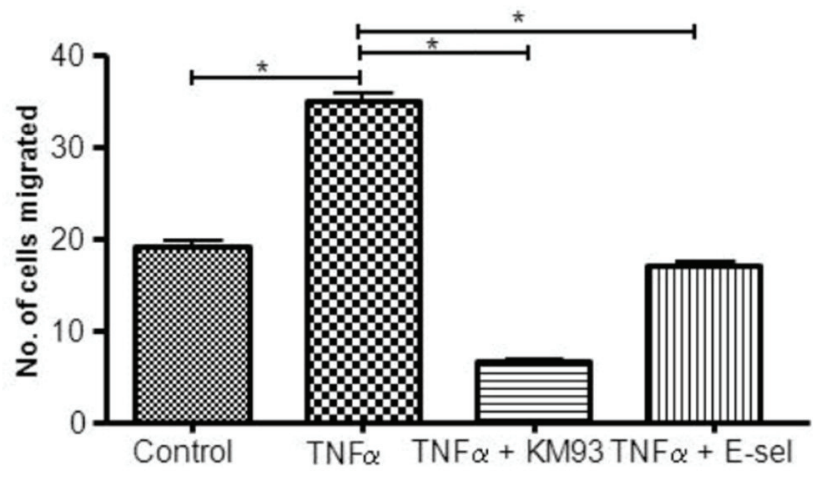

B

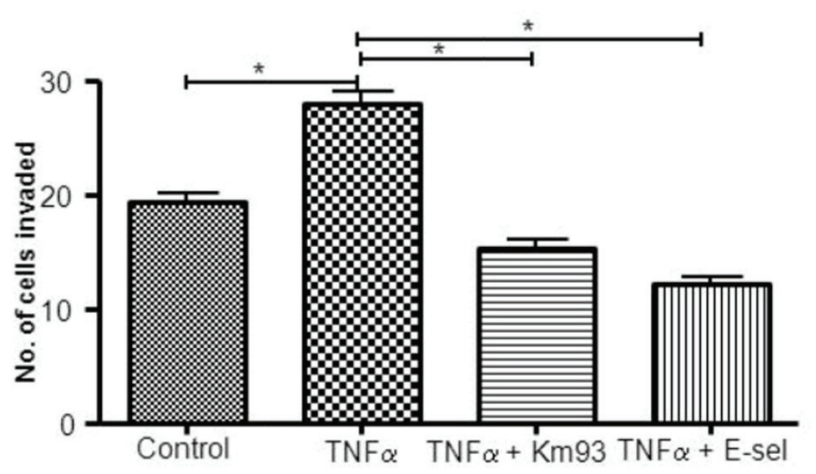

C
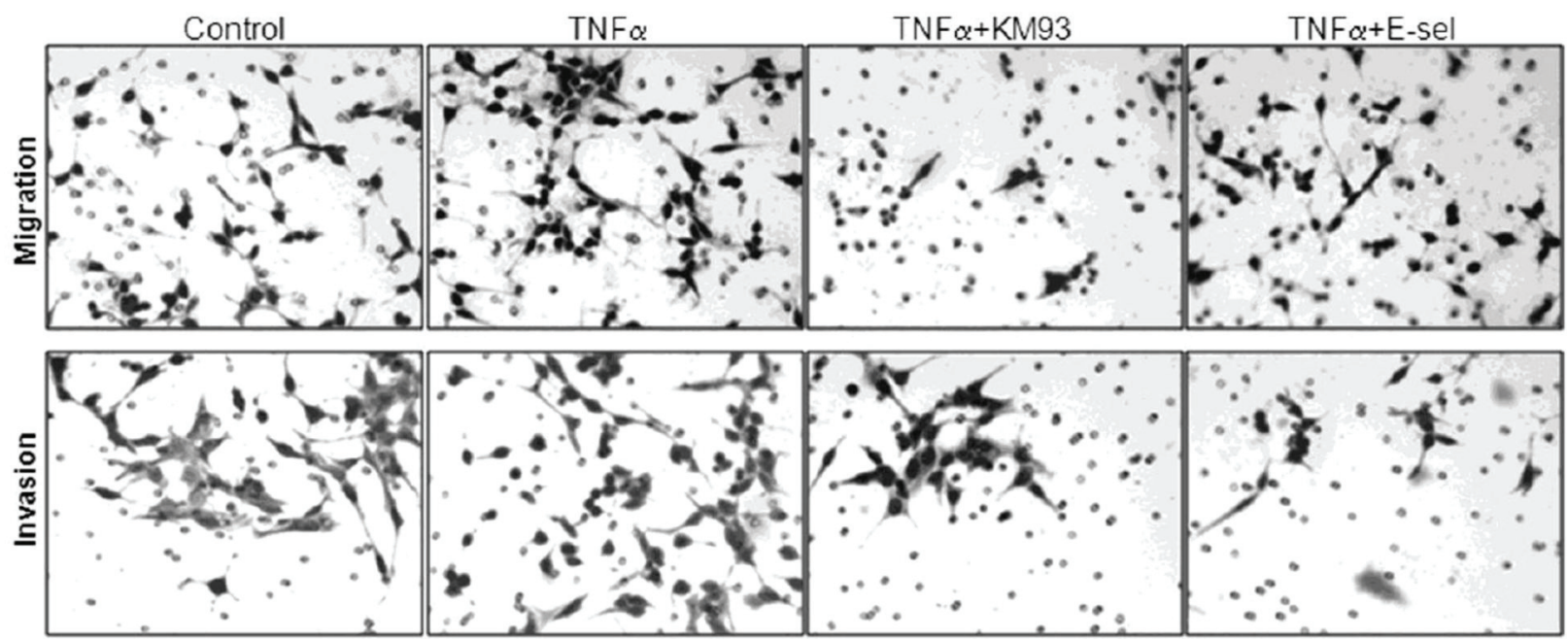

Fig. 4.

Migration and Invasion of LNCaP cells. LNCaP C-81 cells of $5 \times 10^{4}$ cells $/ \mathrm{ml}$ in serum free medium was inoculated in the upper chambers of 24 well migration and matrigel invasion chamber plates. After $24 \mathrm{~h}$, the cells that transverse to bottom side of the chamber plates were fixed, stained, and then counted under a phase contrast microscope (40x) in three independent fields for each insert. The TNFa-treated C-81 cells showed a significantly higher level of migration (A, C) and invasion (B, C) than control cells through polyethylene terapthalate membrane and matrigel invasion chambers, respectively. Pre-incubation of TNFa treated cells with sLe ${ }^{\mathrm{x}}$ specific antibody (KM93) or E-selectin, significantly reduced the number of cells that migrated $(\mathrm{A}, \mathrm{C})$ and invaded $(\mathrm{B}, \mathrm{C})$ when compared with cells treated with TNFa alone. The data represented an average of three independent experiments $(*, \mathrm{p}<0.001)$. 


\section{Table 1}

Oligonucleotide primers used for quantitative real-time PCR analysis of different glycosyl- and sulfotransferases

\begin{tabular}{|l|l|l|}
\hline Genes & Forward primer sequences $\mathbf{5}^{\prime} \mathbf{- 3}^{\prime}$ & Reverse $^{\prime} \mathbf{p r i m e r}$ sequences $\mathbf{5}^{\prime} \mathbf{- 3}^{\prime}$ \\
\hline Core 1 & AGAAGCAAAGGTCACCAGTCCCAA & AGCCAGGATTTAGAGGCCATTTCC \\
\hline B3GnT3 & ATAAGGGAGTGCCAGGGAAGGTTT & ACAGTTGGAACTCTAGCACAGGCA \\
\hline C2GnT1 & GCATGGTTTCTGCAGAGCACAGTT & TTTCCACAATGCCTTGCTACCTGC \\
\hline C2GnT2 & AGAAGCGAGAGCCTTTCACAGACA & TACACAGCTCGCAGTAGCCTTTCA \\
\hline C2GnT3 & GTTCCCTGGGCTTTCCTTGTTTGA & ACTCACCTAAGGCCAAAGGGAACA \\
\hline B4GalT1 & CTAGCAACTTGACCTCGGT & CATTTGGGTTCTGCTTTGCC \\
\hline B4GalT2 & GCATAACGAACCTAACCCTCAG & GCCCAATGTCCACTGTGATA \\
\hline B4GalT3 & GTAACCTCAGTCACCTGCC & ATTCCGCTCCACAATCTCTG \\
\hline B4GalT4 & ACTTCGTGGGTGCCATTCAAGAGA & AAGGAGACACAGAAGGGCAGTTGT \\
\hline B4GalT5 & TGGAACAGAGTACAGAATGCAG & CCTTGCCGTTCTTTTGACTTC \\
\hline B4GalT6 & CTTCACATACTCACCATACCTCC & CCCCTGGCTCAATATCTAAATCC \\
\hline GlcNAc6ST1 & CGAAATGGAGCAGTTTGCCCTGAA & ACTCCTCCACCTGTTTGATCTGCT \\
\hline GlcNAc6ST2 & ATCCCATGAATTTGCTGGGCTACC & AGATGTAGGCAAGGCTCAGAAGCA \\
\hline GlcNAc6ST3 & GCAGACACGCCAAGCTTTGAGAAA & AGCTGCAACGCTGATCACAAATCC \\
\hline GlcNAc6ST4 & TAGTGCAACTTCCTGTGAGCCAGT & TCCATCAAGCCTCACCTCACAACA \\
\hline ST3GAL3 & TGTTCCTGGATGACTCCTTTCGCA & CTTGTTGGCAAGAACGCCTCCATT \\
\hline ST3GAL4 & ATGAGCAGATCACGCTCAAGTCCA & TCCCATCTCCAGCATCCGCTTAAT \\
\hline ST3GAL5 & GCACGGATTAGAACTGGG & CGCCCTCTGGATAAGTCAT \\
\hline ST3GAL6 & TCTATTGGGTGGCACCTGTGGAAA & TGATGAAACCTCAGCAGAGAGGCA \\
\hline FUT3 & AGAGAGATCATCACGGCACGGTTT & ATAAGTGGTGGTCCTGGGCTTGAA \\
\hline FUT4 & TGCAGGTGGGACTTTGTTGTTTGG & TCCTCCAAGGACAATCCAGCACTT \\
\hline FUT5 & TGCCACACTGAATGTCACCTGCTA & TGCTGATGGTCACACACATACCCT \\
\hline FUT6 & ATCACCGCACCGTTTCCAGATGTA & TCCCAAAGTGCTGGGATTACAGGT \\
\hline FUT7 & TTCGTGCATGTGGATGACTTTGGC & AGCGTTGGTATCGGCTCTCATTCA \\
\hline FUT9 & TCCCATGCAGTTCTGATCCAT & CAGCCTCAAGATCATCAGCA \\
\hline GAPDH & TCGACAGTCAGCCGCATCTTCTTT & ACCAAATCCGTTGACTCCGACCTT \\
\hline
\end{tabular}

